\title{
Gospodarski važni virusi jezgričavog voća
}

Economically important viruses of pome fruit

\author{
D. Ivić
}

\section{SAŽETAK}

Virusi jabuke, kruške ili dunje relativno su slabo poznati stručnjacima i voćarima. Najvažnijim virusima koji se javljaju na jezgričavim voćnim vrstama smatraju se virus mozaika jabuke (Apple mosaic virus, ApMV), virus klorotične pjegavosti lista jabuke (Apple chlorotic leaf spot virus, ACLSV), virus brazdavosti debla jabuke (Apple stem grooving virus, ASGV) i virus jamičavosti debla jabuke (Apple stem pitting virus, ASPV). U radu je ukratko opisana njihova važnost, biologija i regulativni status, kao i osnovne mjere zaštite.

Ključne riječi: Apple mosaic virus, Apple chlorotic leaf spot virus, Apple stem grooving virus, Apple stem pitting virus

\section{ABSTRACT}

Virus diseases of apple, pear and quince are relatively less known to agricultural experts and fruit producers. Apple mosaic virus (ApMV), Apple chlorotic leaf spot virus (ACLSV), Apple stem grooving virus (ASGV) and Apple stem pitting virus (ASPV) are usually considered economically most important viruses of pome fruit. Their significance, biology and regulatory status are briefly described, as well as basic control measures.

Key words: Apple mosaic virus, Apple chlorotic leaf spot virus, Apple stem grooving virus, Apple stem pitting virus

\section{UVOD}

Kao i kod svih poljoprivrednih kultura, kod jezgričavih voćnih vrsta javlja se veći broj biljnih virusa koji mogu imati negativan učinak na prinos ili na kakvoću prinosa. Među njima, gospodarski najvažnijima smatraju se Apple mosaic virus (ApMV), Apple chlorotic leaf spot virus (ACLSV), Apple stem grooving virus (ASGV) i Apple stem pitting virus (ASPV). Engleski nazivi virusa mogu se prevesti kao virus mozaika jabuke (ApMV), virus klorotične 
pjegavosti lista jabuke (ACLSV), virus brazdavosti debla jabuke (ASGV) i virus jamičavosti debla jabuke (ASPV). Riječ je o virusima iz različitih rodova $i$ različitog kruga domaćina, no zajedničko im je da su među kultiviranim biljkama njihovi najvažniji domaćini jabuka, kruška i dunja. U usporedbi s gljivičnim i bakterijskim bolestima, važnost virusnih bolesti u proizvodnji spomenutih voćarskih kultura često zanemaruju poljoprivredni proizvođači, no nerijetko i stručnjaci. Glavni razlog tome leži u činjenici da ApMV, ACLSV, ASGV i ASPV, bilo pojedinačno ili kombinirano, kod većine komercijalnih kultivara jabuke i kruške u pravilu ne uzrokuju vidljive simptome (latentne zaraze) ili katkad uzrokuju samo prolazne simptome i naoko ne utječu na produktivnost ili vigor zaraženog stabla. Bez obzira na izostanak vizualno uočljivih simptoma, potvrđeno je da ova četiri virusa mogu imati značajan učinak na prinos i kakvoću prinosa (Massart i sur., 2011.; Jelkmann i Paunovic, 2011.; James, 2001.; Lemoine i Michelesi, 1990.; Németh, 1986.; Cropley i Posnette, 1973.; Campbell, 1963.). U suvremenoj intenzivnoj proizvodnji jabuke, kruške ili dunje svakako je preporučljivo imati u vidu mogući dugoročni negativan učinak koji može biti posljedica zaraze tim virusima.

ApMV, ACLSV, ASGV i ASPV nisu regulirani kao karantenski biljni virusi. Sprječavanje širenja tih virusa u Europskoj Uniji i Hrvatskoj regulirano je europskim i nacionalnim propisima o stavljanju na tržište sadnog materijala voća. Početkom primjene novog zakonodavstva u području biljnog zdravstva od 14. prosinca 2019. godine doći će do promjene u definiranju administrativnog statusa tih virusa. Uredbom (EU) 2016/2031 Europskog parlamenta i vijeća o zaštitnim mjerama protiv organizama štetnih za bilje, koja predstavlja novi zakonodavni okvir u području biljne karantene (biljnog zdravstva) u Uniji, zabranjuje se unošenje i ,premještanje“ reguliranih nekarantenskih štetnih organizama Unije. To su štetni organizmi koji se prenose sjemenom i sadnim materijalom, a trenutno su na razini Unije regulirani direktivama o stavljanju na tržište pojedinih skupina bilja namijenjenih sjetvi ili sadnji. ApMV, ACLSV, ASGV i ASPV regulirani su Provedbenom direktivom Komisije 2014/98/EU o provedbi Direktive Vijeća 2008/90/EZ, kojom se propisuju harmonizirani uvjeti za proizvodnju, certifikaciju i stavljanje na tržište sadnog materijala voća u Uniji. Uvrštavanjem na listu nekarantenskih štetnih organizama Unije, mjere kontrole prisutnosti tih virusa u sadnom materijalu jezgričavih voćnih vrsta $\mathrm{u}$ nekim zemljama Europe mogu se pojačati, što bi moglo imati učinak na trgovinu sadnim materijalom. U svakom slučaju, važnost i status gospodarski važnih virusa jezgričavog voća čine ih uzročnicima bolesti koji zaslužuju pažnju znanstvenika, stručnjaka i voćara. 


\section{POVIJEST I RASPROSTRANJENOST}

Dok je ApMV opisan još 1933. godine kao uzročnik ,infektivne varijegacije“ jabuke (Batford i Joly, 1933), ACLSV, ASGV i ASPV opisani su kao uzročnici različitih bolesti jabuke tijekom 50-tih i 60-tih godina prošlog stoljeća (Lister i sur., 1965.; Guengerich i Millikan, 1959.; Mink i Shay, 1959.). U narednim desetljećima dolazilo se do novih saznanja o ovim virusima (Nemeth, 1986.; Kegler i sur, 1976.; Inouye i sur., 1979.; Fulton, 1972.), no ključan napredak u njihovom istraživanju predstavljao je razvoj molekularnih metoda u biljnoj patologiji od početka 1990-tih godina. Danas postoji nekoliko izolata svakog od ta četiri virusa čiji genom je u potpunosti sekvenciran (Marini i sur., 2008.; Hye Kyung i sur., 2004.; Jelkmann, 1994.; Yoshikava i sur., 1992.), poznata je veličina i struktura njihovog genoma (Shiel i sur., 1995.; Jelkmann, 1994.; Sato i sur., 1993.; Yoshikava i sur., 1992.) i funkcija gena (Jelkmann i Paunovic, 2011.; Petrzik i Lenz, 2011.; Yoshikava i sur., 1992.) te su proširena saznanja o njihovim biljkama domaćinima (Petrzik, 2005.; Desvignes, 1999.; Yoshikava i sur., 1993.; Németh, 1986.). Što je još važnije za poljoprivrednu proizvodnju, razvoj dijagnostičkih metoda omogućio je preciznije utvrđivanje njihove raširenosti na jezgričavom voću u svijetu. Danas se pretpostavlja da su ApMV, ACLSV, ASGV i ASPV prisutni svagdje u svijetu gdje se uzgaja jezgričavo voće.

ApMV, ACLSV, ASGV i ASPV nisu bili predmet znanstvenog izučavanja novijeg datuma u Hrvatskoj. Nekoliko vrijednih radova o tim virusima objavljeno je tijekom 1960-ih i 1970-ih (Pleše, 1975.; Šarić, 1969.; Šarić, 1961.). Realno je za pretpostaviti da su sva četiri virusa prisutna u jabuci, kruški i dunji u Hrvatskoj, no podaci o njihovoj rasprostranjenosti su ograničeni.

\section{TAKSONOMIJA, MORFOLOGIJA I EKOLOGIJA}

ApMV se svrstava u rod Ilarvirus i porodicu Bromoviridae. ACLSV spada $\mathrm{u}$ rod Trichovirus, ASGV u rod Capillovirus, a APMV u rod Foveavirus, pri čemu se sva tri virusa svrstavaju u porodicu Betaflexiviridae.

ApMV je izometričan virus s promjerom viriona oko $30 \mathrm{~nm}$ (Petrzik i Lenz, 2011.). Genom tog virusa sastoji se od tri linearne $(+)$ jednolančane ribonukleinske kiseline (,ssRNA“) koja kodira četiri proteina. Osim kod jabuke i kruške, prirodna zaraza tim virusom zabilježena je kod još 30-tak biljnih vrsta, uglavnom drvenastih. U njegove prirodne domaćine ubrajaju se breza, lijeska, divlji kesten, hmelj, ruže, jagoda, malina, kupina, ribiz i neke vrste koštičavog voća, poput marelice, trešnje i bajama. Osim kod jabuke, ApMV se smatra gospodarski važnim na lijeski. Kod marelice ili trešnje, ApMV može pojačati 
negativan učinak zaraze drugim virusima koštičavog voća, kao što su Prunus necrotic ringspot virus (PNRSV) ili Prune dwarf virus (PDV) (Paunovic i sur., 2011.).

ACLSV je nitasti virus dugačak $680-780 \mathrm{~nm}$ i promjera $12 \mathrm{~nm}$ (Yaegashi i sur., 2011.). Genom ACLSV-a sastoji se od (+) jednolančane ribonukleinske kiseline (,ssRNA“) koja kodira četiri proteina. Osim jabuke, kruške i dunje, ACLSV se javlja u velikom broju voćnih i ukrasnih vrsta iz roda Prunus. Prirodna zaraza tim virusom zabilježena je u većini ukrasnih Malus vrsta, oskoruši i mušmuli. Kod koštičavog voća pojedini izolati tog virusa mogu biti iznimno štetni i uzrokovati simptome slične šarki, bolesti čiji je uzročnik Plum pox virus (PPV). ACLSV je vrlo varijabilan virus, s utvrđenim znatnim molekularnim, serološkim i biološkim razlikama između izolata (Al-Rwahnih i sur., 2004.; Yaegashi i sur., 2007.).

ASGV je nitasti virus dužine $620 \mathrm{~nm}$ i promjera $12 \mathrm{~nm}$, čiji genom se sastoji od (+) jednolančane ribonukleinske kiseline (,ssRNA“) koja kodira tri enzima (Massart i sur., 2011.). Osim u jabuci i kruški, taj virus utvrđen je u ostalom jezgričavom voću, agrumima, kiviju i ljiljanu. Na agrumima se ASGV do nedavno navodio kao Citrus tatter leaf virus (CTLV), no danas se CTLV smatra sojem ASGV-a.

ASPV je nitasti virus dužine $800 \mathrm{~nm}$ i promjera $12-15 \mathrm{~nm}$ (Jelkmann i Paunovic,, 2011.). Genom ASPV-a sastoji se od (+) jednolančane ribonukleinske kiseline (,ssRNA“) koja kodira pet proteina. U usporedi s ostala tri gospodarski važna virusa jezgričavog voća, ASPV ima relativno najuži krug domaćina i do danas je utvrđen u nekoliko vrsta iz rodova Malus, Pyrus, Sorbus, Crategus i u dunji.

Zajedničko obilježje ApMV-a, ACLSV-a, ASGV-a i ASPV-a jest da se prenose samo cijepljenjem i vegetativnim razmnožavanjem zaraženih biljaka. Za niti jedan od ta četiri virusa do danas nisu utvrđeni vektori osim čovjeka odnosno širenja zaraženim sadnim materijalom i zaraženim biljkama domaćinima. Na temelju opažanja, za ApMV, ACLSV i ASPV se navodi da se unutar nasada vjerojatno mogu širiti s biljke u biljku kontaktom (anastomozom) korijena (Jelkmann i Paunovic, 2011.; Petrzik i Lenz, 2011.; Yaegashi i sur., 2011.). Za niti jedan od ta četiri virusa kod jezgričavog voća nije utvrđen prijenos sjemenom ili polenom.

ApMV, ACLSV, ASGV i APMV nerijetko se u jabuci, kruški i dunji javljaju u vidu mješovitih zaraza (Yaegashi i sur., 2011.; Németh, 1986.). Prema rezultatima dosad provedenih istraživanja u različitim zemljama, osobito je čest slučaj da se ACLSV javlja u kombinaciji s ASGV-om ili ASPV-om (Yaegashi i sur., 2011.). 


\section{SIMPTOMATOLOGIJA}

Zaraza ACLSV-om, ASGV-om i APMV-om kod većine komercijalnih kultivara jabuke je latentna, to jest ne dovodi do pojave vidljivih simptoma. ApMV nerijetko uzrokuje pojavu simptoma kod jabuke, iako zaraza i tim virusom može biti latentna. Uočljiv simptom zaraze ApMV-om kod većeg broja kultivara jabuke jest pojava karakterističnog mozaika na listovima. Na listovima se u proljeće javljaju pjege nepravilnog oblika ili pruge uzduž glavnih žila. Listovi izgledaju kao da su prošarani, a boja pjega ili pruga postupno se mijenja iz svjetlozelene u svjetlo žutu do žarkožute ili bijeložute. Navedeni simptomi najuočljiviji su tijekom svibnja i lipnja, nakon čega se mogu povući ili šare postaju nekrotične i poprimaju smeđu boju. Mozaični listovi rjeđe se pojavljuju na čitavom stablu i uglavnom se vide na pojedinačnim izbojima ili listovima. Mozaik na listovima osobito se često javlja na kultivarima Zlatni Delišes, Idared i Jonathan.

Slika 1. Simptomi na listovima jabuke uzrokovani virusom mozaika jabuke (ApMV)

Picture 1 Symptoms caused by apple mosaic virus (ApMV) on apple leaf

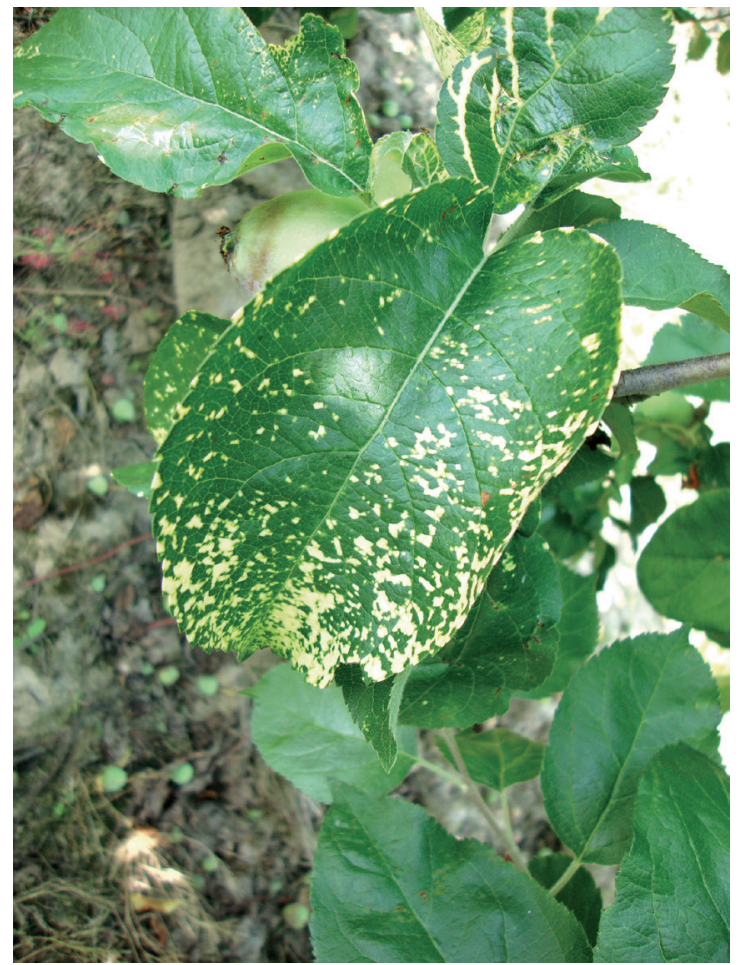


Zaraza kruške i dunje ApMV-om, ACLSV-om i ASGV-om gotovo redovito je latentna i ne dovodi do pojave vidljivih ili karakterističnih simptoma. Za razliku od spomenuta tri virusa, zaraza ASPV-om može dovesti do pojave karakterističnih simptoma kod nekih kultivara kruške i dunje. Na listovima kruške zaraženima tim virusom može se javiti izražena kloroza glavnih žila na listu, što može biti popraćeno pojavom crvenih šara i sitnih pjega. Plodovi krušaka na zaraženim stablima mogu biti kvrgavi, deformirani i tvrdi, pri čemu u njihovom mesu dolazi do pojave sklerenhimskih nakupina (Paunovic i sur., 1999.). Slične simptome „kvrgavosti“ plodova ASPV može uzrokovati i kod dunje (Jelkmann i Paunovic, 2011.). Kultivari kruške kod kojih se najčešće javlja ovakav tip simptoma kao posljedica zaraze ASPV-om su Boskova Bočica i Društvenka, a među dunjama Leskovačka.

Mješovita zaraza jabuke, kruške ili dunje s različitim vrstama virusa također je uglavnom latentna kod većine komercijalnih kultivara tih voćnih vrsta koji su danas zastupljeni u intenzivnoj proizvodnji u Europi. Slabiji razvoj stabala, slabija cvatnja, manji broj plodova ili manja prosječna masa plodova, što može biti posljedica zaraze virusima, vrlo su nespecifični i teško uočljivi simptomi, naročito ako se u obzir uzme činjenica da se često neravnomjerno javljaju u različitim sezonama.

Specifični i vrlo izraženi simptomi zaraze tim virusima javljaju se u slučaju korištenja određenih vrsta podloga i nekih kultivara izvan Europe. U Japanu je zabilježeno masovno propadanje stabala jabuke cijepljenih na podlogu Malus sieboldii uzrokovano ASPV-om i ASGV-om, kao i propadanje stabala i jamičavost debla na podlozi $M$. prunifolia kao posljedica zaraze ACLSV-om (Yaegashi i sur., 2011.). ASPV uzrokuje pojavu jamičavosti debla u slučaju cijepljenja na podlogu M. pumila cv. Virginia Crab, dok se zaraza ASGV-om na istoj podlozi manifestira u vidu pojave brazdavosti debla i nekroze spojnog mjesta između podloge i plemke.

\section{ŠTETNOST I GOSPODARSKA VAŽNOST}

Kao i u slučaju gotovo svih virusnih bolesti višegodišnjih drvenastih kultura, štetnost gospodarski važnih virusa jezgričavog voća ovisi o voćnoj vrsti, kultivaru, starosti i općem stanju zaražene biljke, izolatu virusa, uvjetima uzgoja i godini. Stabla jabuke, kruške ili dunje zaražena ApMV-om, ACLSV-om, ASGVom ASPV-om ili kombinacijom dvaju ili više tih virusa mogu se normalno razvijati i davati rod kao zdrava stabla. Ipak, češći je slučaj da su takva stabla slabije produktivnosti te da zbog virusne zaraze ne mogu u potpunosti ostvariti svoj genetski potencijal rodnosti (Jelkmann i Paunovic, 2011.; Massart i sur., 2011.; Petrzik i Lenz, 2011.; Yaegashi i sur., 2011.; Németh, 1986.). 
Slika 2. Stablo jabuke zaraženo ACLSV-om, ASGV-om i APMV-om (desno) u usporedbi sa zdravim stablom (lijevo) iste starosti. Na zaraženom stablu vidljiv je znatno manji promjer debla i nabreklina na spojnom mjestu.

Picture 2 Apple tree infected with ACLSV, ASGV and APMV (right) in comparison with healthy tree (left) of the same age. Smaller stem diameter and prominent swelling on grafting site are evident on infected tree.

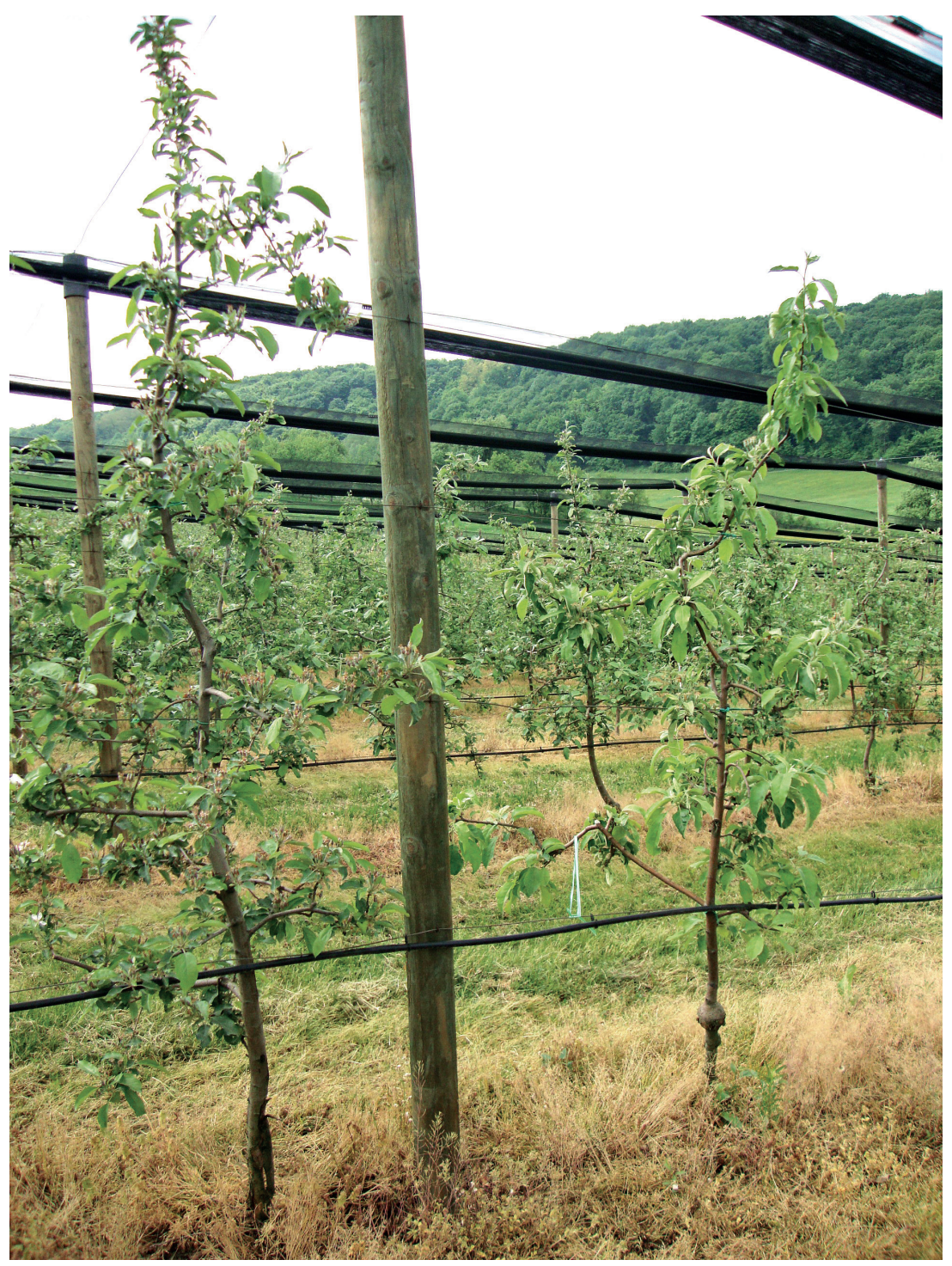


Smanjenje količine i kakvoće prinosa zbog zaraze ApMV-om, ACLSV-om, ASGV-om ASPV-om teško je izraziti preciznim brojkama, što otežava i činjenica da je proveden relativno malen broj istraživanja u kojima bi se kroz duže razdoblje pratio njihov ekonomski učinak u nasadu. Jedno od najdužih takvih istraživanja proveli su Baumann i Bonn (1988.), kroz 13 godina, pri čemu su utvrdili $46 \%$ smanjenja uroda sorte Crveni Delišes zaražene ApMV-om u usporedbi s nezaraženim stablima. Meijnske i sur. (1975.) zabilježili su $12 \%$ manji urod kod sorte Zlatni Delišes zaražene ACLSV-om, ASGV-om i ASPV-om u usporedbi s nezaraženim stablima. Na istom kultivaru i s istim virusima, van Oosten i sur. (1982.) zabilježili su kroz 14 godina $30 \%$ manji urod na zaraženim stablima. Kod kruške je utvrđeno kako su različiti kultivari zaraženi ASPV-om davali 15 - $50 \%$ manji prinos u odnosu na one nezaražene (Lemoine i Michelesi, 1990.), dok je u drugom istraživanju zabilježen do 18 \% manji razvoj promjera debla kod zaraženih biljaka (Cropley i Posnette, 1973.).

James (2001.) je zabilježio da su biljke jabuke nezaražene ASGV-om bile jačeg vigora u odnosu na zaražene biljke. Zaraza ApMV-om može uzrokovati slabiju diferencijaciju pupova, a pretpostavlja se da bi inkompatibilnost nekih podloga dunje s kultivarima kruške mogla biti posljedica zaraze ACLSV-om (Wood, 1997.). Iako to nije egzaktno potvrđeno, na temelju višegodišnjih opažanja se navodi kako zaraza jabuke ApMV-om kroz višegodišnje razdoblje može dovesti do postupnog slabljenja stabla i drastičnog pada produktivnosti biljke nakon dužeg razdoblja (Németh, 1986).

\section{METODE DETEKCIJE}

ApMV, ACLSV, ASGV i ASPV mogu se detektirati biološkim, serološkim i molekularnim metodama. Biološke metode podrazumijevaju korištenje zeljastih ili drvenastih biljaka indikatora, koje na zarazu reagiraju pojavom karakterističnih simptoma. Te tradicionalne metode još uvijek se široko koriste u znanstvenim istraživanjima i za održavanje virusnih izolata, ali i u postupcima dobivanja predosnovnog (,,bezvirusnog“) matičnog sadnog materijala u sustavu certifikacije, iz kojeg se proizvode sadnice ili podloge „visokih“ kategorija. Za detekciju ApMV-a koriste se kultivari jabuke Zlatni Delišes ili Lord Lambourne, na kojima se javlja uočljiv klorotični mozaik na listovima (EPPO, 1999.). Za detekciju ACLSV-a mogu se koristiti indikatori Malus sylvestris kultivar R12740-7A, na kojem se javlja odumiranje vrhova izboja i deformacija listova te dunja C 7/1 ili kruške Nouveau Poiteau ili Frieud 37, na kojima se javlja prstenasti ili linijski mozaik na listovima (EPPO, 1999.). Za ASGV 
preporučuje se $M$. pumila Virginia Crab, na kojoj se javlja brazdavost debla, M. micromalus GMAL 273, koji reagira pojavom klorotičnih pjega i nekrozom stabljike ili zeljasta biljka Chenopodium quinoa (EPPO, 1999.). Za detekciju ASPV-a koriste se M. pumila Virginia Crab ili Pyronia veitchii, na kojima dolazi do pojave rupičavosti u ksilemu (EPPO, 1999.).

Tehnike cijepljenja ili inokulacije na biljke indikatore su dugotrajne i nepraktične. Danas se u rutinskoj dijagnostici virusa jezgričavog voća uglavnom koriste serološke i molekularne metode. ELISA je najčešća i vrlo praktična serološka metoda koja se može koristiti u masovnom testiranju, a za sva četiri virusa razvijene su i molekularne metode detekcije, poput RT-PCR-a ili IC-RT-PCR-a (Hassan i sur., 2006.; Spiegel i sur., 2006.; Menzel i sur., 2002.; Jelkmann i Keim-Konrad, 1997.; Kinrad i sur., 1996.).

\section{MJERE ZAŠTITE I ZAKONSKI PROPISI}

Prirodni vektori ApMV-a, ACLSV-a, ASGV-a i ASPV-a nisu poznati i glavni način kojim se ti virusi prenose jest vegetativno razmnožavanje zaraženih biljaka. Sukladno tome, temeljni i najučinkovitiji način sprječavanja zaraze i prijenosa tih virusa je proizvodnja nezaraženog sadnog materijala. Proizvodnjom sadnica jabuke, kruške ili dunje prema certifikacijskoj shemi moguće je vrlo učinkovito kontrolirati prisutnost ApMV-a, ACLSV-a, ASGV-a i ASPV-a $\mathrm{i}$ to je praksa koja se primjenjuje u gotovo svim državama sa suvremenom intenzivnom proizvodnjom jezgričavog voća. Prisutnost tih virusa kontrolira se u početnom (predosnovnom) matičnom materijalu jezgričavog voća osjetljivim testovima, nakon čega se nezaraženi materijal razmnožava kroz nekoliko kontroliranih koraka i uz visoku razinu kontrole. Proizvodnja prema certifikacijskoj shemi s vrlo visokom sigurnošću jamči odsutnost tih virusa $\mathrm{u}$ sadnicama jabuke, kruške ili dunje kategorije 'certificirani' sadni materijal, u praksi često nazivanog i ,bezvirusni“" sadni materijal. Iz tog, ali i drugih razloga vezanih uz sortnu čistoću i zdravstveno stanje općenito, profesionalni uzgajivači jabuke, kruške ili dunje trebali bi prednost davati i ponajprije koristiti sadni materijal kategorije 'certificirani'.

Stavljanje sadnog materijala jezgričavog voća na tržište, certifikacija sadnog materijala $\mathrm{i}$ stručni nadzor nad proizvodnjom takvog materijala trenutno su $\mathrm{u}$ Hrvatskoj regulirani Zakonom o sjemenu, sadnom materijalu i priznavanju sorti poljoprivrednog bilja (Narodne novine 140/05, 35/08, 25/09, 124/10, 55/11, 14/14, 115/18). Na temelju spomenutog zakona, 2017. godine usvojen je trenutno važeći Pravilnik o stavljanju na tržište reprodukcijskog sadnog materijala i sadnica namijenjenih za proizvodnju voća (Narodne novine 9/17). 
Taj pravilnik usklađen je s Direktivom Vijeća 2008/90/EZ od 29. rujna 2008. o stavljanju na tržište reprodukcijskog sadnog materijala i sadnica namijenjenih proizvodnji voća, čak četiri godine nakon ulaska Hrvatske u Europsku uniju i obveze usklađivanja europske pravne stečevine. Trenutno važeći pravilnik propisuje da se svaka predosnovna matična biljka kandidatkinja jabuke, kruške i dunje laboratorijski testira na prisutnost ApMV-a, ACLSV-a, ASGV-a i ASPVa (jabuka) ili ACLSV-a, ASGV-a i ASPV-a (kruška i dunja). Laboratorijska analiza je jamstvo da se ti virusi neće prenositi na potomstvo i da neće biti prisutni u certificiranim sadnicama kao konačnim proizvodima. Uz to, sve matične biljke kategorije predosnovna, osnovna i certificirana vizualno se pregledavaju svake godine te se obavezno testiraju u slučaju sumnje na zarazu.

$\mathrm{Za}$ razliku, od sadnog materijala jezgričavog voća proizvedenog prema certifikacijskoj shemi, kontrola ApMV-a, ACLSV-a, ASGV-a i ASPV-a u sadnom materijalu CAC kategorije kontrolira se samo vizualnim pregledom. Zbog nerijetko latentnih zaraza, vizualnim pregledom uglavnom se ne može uočiti prisutnost tih virusa u matičnim biljkama. Iz tog razloga puno je veća vjerojatnost da sadni materijal jabuke, kruške ili dunje CAC kategorije bude zaražen ApMV-om, ACLSV-om, ASGV-om ili ASPV-om.

Novost u regulatornom statusu tih virusa donosi nova Uredba (EU) 2016/2031 Europskog parlamenta i vijeća o zaštitnim mjerama protiv organizama štetnih za bilje. Ta uredba stupa na snagu sredinom prosinca 2019 ., izravno je primjenjiva u svim državama članicama i predstavlja novi krovni propis kojim se regulira biljno zdravstvo u Europskoj uniji. Uredbom su ApMV, ACLSV, ASGV i ASPV dobili status ,nekarantenskih reguliranih štetnih organizama“. Prema spomenutoj uredbi, ti štetni organizmi ne smiju se unositi niti premještati na području Europske unije u bilju namijenjenom sadnji. Ostaje za vidjeti hoće li takve odredbe imati praktičan učinak na trgovinu sadnim materijalom jezgričavog voća proizvedenim u Hrvatskoj. Potencijalni problemi su mogući kod izvoza sadnog materijala CAC kategorije, za kojeg je spomenut relativno visok rizik da je zaražen gospodarski važnim virusima jezgričavog voća.

\section{LITERATURA}

AL-RWAHNIH, M., TURTURO, C., MINAFRA, A., SALDARELli, P., MYRTA, A., PALLÁS, V., SAVINO, V. (2004): Molecular variability of apple chlorotic leaf spot virus in different hosts and geographical regions. Journal of Plant Pathology 86: 117-122. 
BAUMANN, G., BONN, G.E. (1988.): Einflub von Apfelmosaik und Gummiholzkrankheit auf Die Vegetative und Generative Leistung von Apfelsorten auf M 9 bis zum 13 Standjahr. Erwerbsobstbau 30: 162-165.

BRADFORT, F.C., JOLY, L. (1933.): Infectious variegation in the apple. Journal of Agricultural Research 46: 901-908.

CAMPBELL, A.I. (1963.): The effect of some latent virus infections on the growth and cropping of apples. Journal of Horicultural Science 38: 15-19.

CROPLEY, R., POSNETTE, A.F. (1973.): The effect of viruses on growth and croping of pear trees. Annals of Applied Biology 73: 39-43.

DESVIGNES J.C. (1999.): Apple stem grooving virus. In: Virus Diseases of Fruit Trees. CTIFL, Lanxade, pp. 155-156.

EPPO (1999.): Pathogen-tested material of Malus, Pyrus and Cydonia. Certification schemes PM 4/27(1). Bulletin EPPO/OEPP Bulletin 29: 239-252.

FULTON, R.W. (1972.): Apple mosaic virus. AAB, Descriptions of Plant Viruses No. 83.

GUENGERICH, H.W., MILLIKAN, D.F. (1959.): Reaction of ownrooted trees of Spy 227 and Virginia Crab to infection with stem pitting virus. Plant Disease Report 254: 30-31.

HASSAN, M., MYRTA, A., POLAK, J. (2006.): Simultaneous detection and identification of four pome fruit viruses by one-tube pentaplex RT-PCR. Journal of Virological Methods 133: 124-129.

HYE KYUNG, S., YEON JU, M., SUNG YOUL, H., MOON SIK, K., DAE HYUN, K., HYUN RAN, R., YONG MOON, C., SUK CHAN, L., JAE MYUNG, Y. (2004.): Nucleotide sequences of a Korean isolate of apple stem grooving virus associated with black necrotic leaf spot disease on pear (Pyrus pyrifolia). Molecules and Cells 18: 192-199.

INOUYE, N., MAEDA, T., MITSUHATA, K. (1979.): Citrus tatter leaf virus isolated from Lily. Annals of the Phytopathological Society of Japan 45: 712-720.

JAMES, D. (2001.): Long term assessment of the effects of in vitro chemotherapy as a tool for apple stem grooving virus elimination. Acta Horticulturae 550: 462-559. 
JELKMANNN, W. (1994.): Nucleotide sequences of apple stem pitting virus and of the coat protein gene of a similar virus from pear associated with vein yellows disease and their relationship with potex - and car - laviruses. Journal of General Virology 75: 1535-1542.

JELKMANN, W., KEIM-KONRAD, R. (1997.): An immuno - capture polymerase chain reaction and plate - trapped ELISA for the detection of apple stem pitting virus. Journal of Phytopathology 145: 499-504.

JELKMANN, W., PAUNOVIC, S. (2011.). Apple stem pitting virus. In: Virus and Virus-Like Diseases of Pome and Stone Fruits (Hadidi, A., Barba, M., Candresse, T., Jelkmann, W., eds.), APS Press, St. Paul, pp. 35-40.

KEGLER, H., KLEINHEMPEL, H., VERDEREVSKAJA, T.D. (1976.): Investigations on pear stony pit virus. Acta Horticulturae 67: 209-217.

KINARD, G. R., SCOTT, S. W., BARNETt, O. W. (1996.): Detection of apple chlorotic leaf spot and apple stem grooving viruses using RT-PCR. Plant Disease 80: 616-621.

LEMOINE, J., MICHELESI, J.C. (1990.): Effects of three virus - diseases on three pear cultivars. Scientia Horticulturae 44: 69-81.

LISTER, R. M., BANCROFT, J.B., and Nadakavukaren, M.J. (1965.): Some saptransmissible viruses from apple. Phytopathology 55: 859-870.

MARINI, D.B., GIBSON, P.G., SCOTT, S.W. (2008.): Complete nucleotide sequence of an isolate of apple chlorotic leaf spot virus from peach (Prunus persica (L.) Batch). Archives of Virology 153: 1003-1005.

MASSART, S., JIJAKLI, M.H., KUMMERT, J. (2011.): Apple stem grooving virus. In: Virus and Virus-Like Diseases of Pome and Stone Fruits (Hadidi, A., Barba, M., Candresse, T., Jelkmann, W., eds.), APS Press, St. Paul, pp. 29-33.

MEIJNSKE, C.A.R., VAN OOSTEN, H.J., PEERBOOMS, H. (1975.): Growth, yield and fruit quality of virus-infected and virus-free 'Golden Delicious' apple trees. Acta Horticulturae 44: 209-212.

MENZEL, W., JELKMANN, W., MAISS, E. (2002.): Detection of for apple viruses by multiplex RT-PCR assays with coamplification of plant mRNA as internal control. Journal of Virological Methods 99: 81-92. 
MINK, G.I., SHAY, J.R. (1959.): Preliminary evaluation of some Russian apple varieties as indicators of apple viruses. Plant Disease Reporter Supplement 254: 13-17.

NÉMETH, M. (1986.): Virus, Mycoplasma and Rickettsia Diseases of Fruit Trees. Akadémiai Kaidó, Budimpešta.

PAUNOVIC, S., MAKSIMOVIC, V., RANKOVIC, M., RADOVIC, S. (1999.): Characterization of a virus associated with pear stony pit in $\mathrm{cv}$. Wurttemberg. Journal of Phytopathology 147: 695-700.

PAUNOVIC, S., PASQUINI, G., BARBA, M. (2011.): Apple chlorotic leaf spot virus. In: Virus and Virus-Like Diseases of Pome and Stone Fruits (Hadidi, A., Barba, M., Candresse, T., Jelkmann, W., eds.), APS Press, St. Paul, pp. 91-95.

PETRZIK, K. (2005.): Capsid protein sequence gene analysis of apple mosaic virus infecting pears. European Journal of Plant Pathology 111: 355-360.

PETRZIK, K., LENZ, O. (2011.): Apple mosaic virus in Pome Fruits. In: Virus and Virus-Like Diseases of Pome and Stone Fruits (Hadidi, A., Barba, M., Candresse, T., Jelkmann, W., eds.), APS Press, St. Paul, pp. 25-28.

PLEŠE, N, HOXA, E, MILIČIĆ, D. (1975.): Pathological anatomy of trees affected with apple stem grooving virus. Phytopathologische Zeitschrift 82: 315-325.

SATO, K., YOSHIKAWA, N., TAKAHASHI, T. (1993.): Complete nucleotide sequence of the genome of an apple isolate of apple chlorotic leaf spot virus. Journal of General Virology 74: 1927-1931.

SHIEL, P. J., ALREFAI, R. H., DOMIER, L. L., KORBAN, S. S., BERGER, P. H. (1995.): The complete nucleotide sequence of Apple mosaic virus RNA-3. Archives of Virology 147: 1247-1256.

SPIEGEL, S., THOMPSON, D., VARGA, A., ROSNER, A., JAMES, D. (2006.): Evaluation of reverse transcription - polymerase chain reaction assays for detecting Apple chlorotic leaf spot virus in certification and quarantine programs. Canadian Journal of Plant Pathology 28: 280-288.

ŠARIĆ, A. (1961.): Mozaik jabuke. Biljna Zaštita 1: 12-13.

ŠARIĆ, A. (1969.): Zaraze s latentnim virusima u nekim sortama jabuke. Poljoprivredna Znanstvena Smotra 26: 3-12. 
VAN OOSTEN, H.J., MEIJNSKE, C.A.R., PEERBOOMS, H. (1982.): Growth, yield and fruit quality of virus-infected and virus-free 'Golden Delicious' apple trees, 1968-1982. Acta Horticulturae 130: 213-220.

WOOD, G. A. (1997.): Viruses and phytoplasma in European pear trees in New Zealand and the role of these pathogens in the compatibility of pear with quince rootstocks. New Zealand Journal of Crop and Horticultural Science 25: 333-340.

YAEGASHI, H., ISOGAI, M., TAJIMA, H., SANO, T., YOSHIKAWA, N. (2007.): The combinations of the two amino acids (Ala40 and Phe75 or Ser40 and Tyr75) in the Coat Protein of Apple chlorotic leaf spot virus are crucial for infectivity. Journal of General Virology 88: 2611-2618.

YAEGASHI, H., YOSHIKAWA, N., CANDRESSE, T. (2011.): Apple chlorotic leaf spot virus in Pome Fruits. In: Virus and Virus-Like Diseases of Pome and Stone Fruits (Hadidi, A., Barba, M., Candresse, T., Jelkmann, W., eds.), APS Press, St. Paul, pp. 17-24.

YOSHIKAWA, N., SASAKI, E., KATO, M., TAKAHASHI, T. (1992.): The nucleotide sequence of apple stem grooving capilovirus genome. Virology 191: 98-105.

YOSHIKAWA, N., IMAIZUMI, M., TAKAHASHI, T., INOUYE, N. (1993.): Striking similarities between the nucleotide-sequence and genome organisation of citrus tatter leaf and apple stem grooving capillovirus. Journal of General Virology 74: 2743-2747.

\section{Adresa autora - Authors address:}

dr. sc. Dario Ivić, e-mail: dario.ivic@hapih.hr

Centar za zaštitu bilja, Hrvatska agencija za poljoprivredu i hranu

Gorice 68b, 10000 Zagreb 